\title{
Effect of Amine Type on the Expression of Plasmid DNA by Cationized Dextran
}

\author{
AUTHOR(S): \\ Jo, Jun-ichiro; Nagane, Kentaro; Yamamoto, \\ Masaya; Tabata, Yasuhiko
}

\section{CITATION:}

Jo, Jun-ichiro ... [et al]. Effect of Amine Type on the Expression of Plasmid DNA by

Cationized Dextran. Journal of Biomaterials Science, Polymer Edition 2010, 21(2): 225-236

ISSUE DATE:

2010

URL:

http://hdl.handle.net/2433/148427

RIGHT:

(c) Koninklijke Brill NV, Leiden, 2010 


\title{
Effect of Amine Type on the Expression of Plasmid DNA by Cationized Dextran
}

\author{
Jun-ichiro Jo ${ }^{\text {a }}$, Kentaro Nagane ${ }^{\mathrm{a}}$, Masaya Yamamoto ${ }^{\mathrm{a}, \mathrm{b}}$ and Yasuhiko Tabata ${ }^{\mathrm{a}, *}$ \\ ${ }^{a}$ Department of Biomaterials, Institute for Frontier Medical Sciences, Kyoto University, \\ 53 Kawara-cho Shogoin, Sakyo-ku, Kyoto 606-8507, Japan \\ ${ }^{\mathrm{b}}$ PRESTO, JST, 4-1-8 Honcho, Kawaguchi-shi, Saitama 332-0012, Japan
}

Received 7 December 2008; accepted 20 January 2009

\begin{abstract}
The objective of this study is to prepare a non-viral carrier of gene expression from the polysaccharide dextran and evaluate the effect of amine compounds introduced to dextran on the level of gene expression. Dextran with a molecular weight of $74 \times 10^{3}$ was cationized by the chemical introduction of different amine compounds. The cationized dextran was complexed with a plasmid DNA and the vitro gene transfection was investigated for HeLa cells. The level of gene expression depended on the amine compound introduced to dextran. The highest level was observed for the complex of spermine-introduced dextran and plasmid DNA. The highest cellular internalization and the best buffering effect were observed among every cationized dextran. Every complex did not show any cytotoxicity. It is concluded that the superior properties of spermine-introduced dextran enabled the plasmid DNA to enhance the expression level to a great extent compared with other cationized dextrans. Cationized dextran is a promising non-viral carrier of plasmid DNA.

(C) Koninklijke Brill NV, Leiden, 2010
\end{abstract}

\section{Keywords}

Cationized dextran, amine compound, gene expression

\section{Introduction}

Gene transfection technologies play a great important role not only in gene therapy, which is one of the promising approaches to treat human diseases with nucleic acids (therapeutic genes, antisense sequence oligo-deoxynucleotides and small interference RNA) [1], but also in preparation of cells genetically engineered for the basic research of cell biology and cell-based therapy. Thus, several researches have been performed to develop the material and technology for gene transfection. Generally the carrier for gene delivery is classified into the viral and non-viral types. A vi-

\footnotetext{
* To whom correspondence should be addressed. Tel.: (81-75) 751-4121; Fax: (81-75) 751-4646; e-mail: yasuhiko@ frontier.kyoto-u.ac.jp 
ral carrier of adenovirus [2] and retrovirus [3] has a high transfection efficiency, but there are some issues to be resolved before clinical application, such as the mutagenesis, cacinogenesis and immune responsiveness. In spite of a lower transfection efficiency than the viral carrier, the non-viral carrier has some advantages in terms of the biological safety, lower immunogenicity, no size limitation of gene to deliver, and easy preparation. From this practical viewpoint, several researches about the non-viral carriers have been widely performed. Many types of cationized polymers [4] and cationized liposomes [5-7] have been designed [8-10] and the complexation enabled plasmid DNA to neutralize the anionic charge as well as to reduce the molecular size, which is preferable to enhance the efficiency of plasmid DNA transfection.

Among the non-viral materials applicable for gene transfection carrier, polysaccharides have some advantages over other substances. Most polysaccharides are water-soluble and have a long history of medical, pharmaceutical and food applications. The biosafety and bioavailability have been proven in terms of the practical usage. A sample with different physicochemical properties, such as the molecular weight, electric charge and water solubility, is practically available. Since polysaccharide has reactive groups, the chemical modification can be readily made to change the chemical, physical and biological functions. Another notable feature of polysaccharides is that they are composed of different sugars which can be recognized by the respective cell receptors with a sugar specificity. For example, several researchers demonstrated that dextran $[11,12]$ functions as a ligand for the mannose receptor. This biological recognition not only permits the receptor-specific targeting of agents to the cell, but also accelerates their cell uptake via receptormediated endocytosis. We have designed a non-viral carrier of gene transfection from polysaccharides, for example, dextran and pullulan, and demonstrated the feasibility to enhance the transfection of plasmid DNA for stem cells [13].

It is well recognized that the level of gene expression is greatly influenced by the physicochemical properties of cationized carriers for complexation including the molecular weight, and the type of amine compounds or the extent for cationization. Among them, amine compounds introduced to the carrier polymer has been recognized as a factor contributing to not only the physicochemical properties of carrier polymer-DNA complexes, but also the level of gene expression [14-19]. In this study, thus, various amine compounds were chemically introduced to the dextran of a polysaccharide, and a plasmid DNA was complexed with the cationized dextran derivatives. In addition to the acid-base titration of cationized dextran derivatives, apparent molecular size and zeta potential measurement, gel retardation and ethidium bromide (EtBr) intercalation assays of the complexes were carried out to evaluate the physicochemical properties of complexes. In vitro gene expression by the complexes was investigated for HeLa cells to evaluate the influence of the complex physicochemical properties. 
<smiles>NCCN</smiles>

(A)<smiles>CCNCCN</smiles>

(B)<smiles>CCN(CC)CCN</smiles>

(C)<smiles>NCCCCNCCCCN</smiles>

(D)<smiles>NCCCNCCCCNCCCN</smiles>

(E)

Figure 1. Chemical structure of amine compounds used for the cationization of dextran: (A) ethylenediamine (N2N), (B) N-ethylethylenediamine (N2N2), (C) N,N-diethylethylenediamine (N2N2,2), (D) spermidine $(\mathrm{N} 3 \mathrm{~N} 4 \mathrm{~N})$ and $(\mathrm{E})$ spermine $(\mathrm{N} 3 \mathrm{~N} 4 \mathrm{~N} 3 \mathrm{~N})$.

\section{Materials and Methods}

\subsection{Materials}

Dextran with a weight-average molecular weight of $74 \times 10^{3}$ and amine compounds (Fig. 1) ethylenediamine (N2N), N-ethylethylenediamine (N2N2), N,Ndiethylethylenediamine $(\mathrm{N} 2 \mathrm{~N} 2,2)$, spermidine $(\mathrm{N} 3 \mathrm{~N} 4 \mathrm{~N})$ and spermine $(\mathrm{N} 3 \mathrm{~N} 4 \mathrm{~N} 3 \mathrm{~N})$ were purchased from Sigma-Aldrich (St. Louis, MO, USA). Other chemicals were obtained from Nacalai Tesque (Kyoto, Japan) and used without further purification.

\subsection{Preparation of Cationized Dextran Derivatives}

Each amine compound was chemically introduced to the hydroxyl groups of dextran by a $\mathrm{N}, \mathrm{N}^{\prime}$-carbonyldiimidazole (CDI) activation method [20]. Briefly, $9.28 \times$ $10^{-3} \mathrm{~mol}$ of each amine compound and $4.64 \times 10^{-3}$ mol CDI were added to $50 \mathrm{ml}$ dehydrated dimethyl sulfoxide containing $50 \mathrm{mg}$ dextran. Following agitation at $35^{\circ} \mathrm{C}$ for $20 \mathrm{~h}$, the reaction mixture was dialyzed against an ultra-pure doubledistilled water (DDW) for 2 days with a dialysis membrane (molecular weight cut-off $(12-14) \times 10^{3}$, Viskase, Willowbrook, IL, USA). Then, the solution dialyzed was freeze-dried to obtain the amine-introduced dextran (cationized dextran). When determined from the conventional elemental analysis, the molar percentages of amine compounds introduced to the hydroxyl groups of dextran were 36.2, 26.3, $34.3,25.8$ and $23.9 \mathrm{~mol} \%$ for $\mathrm{N} 2 \mathrm{~N}, \mathrm{~N} 2 \mathrm{~N} 2, \mathrm{~N} 2 \mathrm{~N} 2,2, \mathrm{~N} 3 \mathrm{~N} 4 \mathrm{~N}$ and $\mathrm{N} 3 \mathrm{~N} 4 \mathrm{~N} 3 \mathrm{~N}$, respectively (Table 1).

\subsection{Preparation of Plasmid DNA}

The plasmid DNA used was the pGL3 vector $(5.26 \mathrm{~kb})$ coding a firefly luciferase gene (Luciferase Reporter Vectors-pGL3, Promega, Madison, WI, USA). The plasmid DNA was propagated in an Escherichia coli strain (DH5 $\alpha$ ) and purified using a Qiagen plasmid Mega kit (Qiagen, Tokyo, Japan) according to the manufacturers' instructions. Both the yield and purity of the plasmid DNA were evaluated by UV spectroscopy (Ultrospec 2000, Pharmacia Biotech, Cambridge, UK). The absorbance ratio at wavelengths of 260 to $280 \mathrm{~nm}$ for plasmid DNA solution was measured to be between 1.8 and 2.0. 
Table 1.

Physicochemical properties and cellular internalization of plasmid DNA and the complexes with dextran cationized by different amine compounds at a N/P ratio of 5.0

\begin{tabular}{lllclc}
\hline $\begin{array}{l}\text { Amine } \\
\text { compound }\end{array}$ & $\begin{array}{l}\text { Percent } \\
\text { introduced }\end{array}$ & $\mathrm{p} K_{\mathrm{a}}$ & $\begin{array}{l}\text { Apparent molecular } \\
\text { size }(\mathrm{nm})\end{array}$ & $\begin{array}{l}\text { Zeta potential } \\
(\mathrm{mV})\end{array}$ & $\begin{array}{l}\text { Percent } \\
\text { internalized }\end{array}$ \\
\hline $\mathrm{N} 2 \mathrm{~N}$ & 36.2 & 7.38 & $306 \pm 105$ & $+9.22 \pm 1.4$ & 9.7 \\
$\mathrm{~N} 2 \mathrm{~N} 2$ & 26.3 & 8.64 & $3330 \pm 1750$ & $+9.78 \pm 1.3$ & 5.0 \\
$\mathrm{~N} 2 \mathrm{~N} 2,2$ & 34.3 & 9.08 & $230 \pm 33.4$ & $+11.1 \pm 1.0$ & 13.5 \\
N3N4N & 25.8 & $9.64,7.15$ & $235 \pm 66.7$ & $+16.3 \pm 1.1$ & 19.8 \\
N3N4N3N & 23.9 & $9.98,8.02,7.16$ & $221 \pm 77.5$ & $+16.3 \pm 1.4$ & 33.7 \\
$\begin{array}{l}\text { Free plasmid } \\
\text { DNA }\end{array}$ & & & $655.8 \pm 331.1$ & $-14.9 \pm 4.6$ & 2.0 \\
\hline
\end{tabular}

Percent introduced indicates the extent of amine compounds introduced to the hydroxyl groups of dextran. $\mathrm{p} K_{\mathrm{a}}$ was determined by acid-base titration. Apparent molecular size and Zeta potential values are means $\pm \mathrm{SD}$.

\subsection{Acid-Base Titration of Cationized Dextran}

Each cationized dextran with the similar molar amount of amino groups $(6.0 \times$ $10^{-7} \mathrm{~mol}$ ) was dissolved in DDW. To deprotonize all of amino groups in the cationized dextran, $60 \mu \mathrm{l} 0.01 \mathrm{M} \mathrm{NaOH}$ was added. Potentiometric titration was performed with a Horiba F22 $\mathrm{pH}$ meter (Horiba, Kyoto, Japan) using $0.001 \mathrm{M} \mathrm{HCl}$. From the titration curve, the $\mathrm{p} K_{\mathrm{a}}$ values of cationized dextran were determined based on the Henderson-Haselbalch equation.

\subsection{Preparation of Polyion Complexes}

Polyion complexes (PICs) were prepared by mixing an aqueous solution of cationized dextran with that of plasmid DNA. Briefly, varied amounts of cationized dextran were dissolved in $25 \mu \mathrm{lDDW}$ and mixed with $25 \mu \mathrm{l} 10 \mathrm{mM}$ phosphate-buffered saline solution (PBS, pH 7.4) containing $2.5 \mu \mathrm{g}$ plasmid DNA, followed by leaving for $15 \mathrm{~min}$ at room temperature to obtain various PICs of cationized dextran and plasmid DNA. The PIC composition was calculated on the basis of the nitrogen number of cationized dextran $(\mathrm{N})$ per the phosphorus number of plasmid DNA $(\mathrm{P})$ and expressed as the N/P ratio.

\subsection{Electrophoresis of Cationized Dextran-Plasmid DNA Complexes}

PICs were prepared in $10 \mathrm{mM}$ PBS solution at different N/P ratios. After $15 \mathrm{~min}$ of incubation, $10 \mu \mathrm{l}$ of the complex was added to $3 \mu \mathrm{l}$ loading buffer $(0.1 \%$ sodium dodecyl sulfate, $5 \%$ glycerol and $0.005 \%$ bromophenol blue) and applied on an $1 \mathrm{wt} \%$ agarose gel in tris-borate-ethylenediaminetetraacetic acid buffer solution (TBE, $\mathrm{pH}$ 8.3) containing $0.1 \mathrm{mg} / \mathrm{ml}$ ethidium bromide (EtBr). Electrophoretic evaluation of the PICs was carried out in TBE solution at $100 \mathrm{~V}$ for $30 \mathrm{~min}$. The gel was imaged with a UV transilluminator (Gel Doc 2000, Bio-Rad Laboratories, Segrate, Italy). 


\subsection{Dynamic Light Scattering (DLS) and Electrophoretic Light Scattering (ELS) Measurements of PICs}

PIC were prepared in $10 \mathrm{mM}$ PBS solution at a N/P ratio of 5.0. DLS measurements were carried out using a DLS-DPA-60HD instrument (Otsuka Electronic, Osaka, Japan) equipped with an $\mathrm{Ar}^{+}$laser at a detection angle of $90^{\circ}$ at $25^{\circ} \mathrm{C}$ for $15 \mathrm{~min}$. In the present study, the autocorrelation function of samples was analyzed based on the cumulants method and the $R_{\mathrm{s}}$ value was calculated automatically by the equipped computer software and expressed as the apparent molecular size of samples. On the other hand, the zeta potential was measured using ELS-7000AS instrument (Otsuka Electronic) at $25^{\circ} \mathrm{C}$ and an electric field strength of $100 \mathrm{~V} / \mathrm{cm}$. From the determined electrophoretic mobility, the zeta potential was automatically calculated using the Smoluchowski equation. Light scattering measurement was done three times for every sample.

\subsection{Ethidium Bromide Intercalation Assay}

A sample containing plasmid DNA $(20 \mu \mathrm{g} / \mathrm{ml})$ and $\mathrm{EtBr}(0.4 \mathrm{mg} / \mathrm{ml})$ (plasmid DNA-EtBr complex) was used to calibrate to $100 \%$ fluorescence. The cationized dextran was added to an aqueous solution of DNA-EtBr complex at different $\mathrm{N} / \mathrm{P}$ ratios. The fluorescence intensity of the samples (excitation $510 \mathrm{~nm}$, emission $590 \mathrm{~nm}$ ) was measured 15 min later by Gemini EM fluorescent microplate reader (Molecular Devices, Sunnyvale, CA, USA). The results were expressed as a relative fluorescence intensity (percent decrease against plasmid DNA-EtBr complex).

\subsection{In Vitro Gene Transfection Experiment}

Transfection experiments were performed in triplicate. HeLa cells were purchased from American Type Culture Collection (Manassas, VA, USA), and maintained in Dulbecco's Modified Eagle Medium supplemented with $110 \mathrm{mg} / \mathrm{ml}$ sodium pyruvate (Invitrogen, Carlsbad, CA, USA), and 10 vol\% fetal calf serum (Hyclone Laboratories, South Logan, UT, USA) (DMEM-FCS) at $37^{\circ} \mathrm{C}$. Cells were seeded in each well of 12 multi-well cluster plate (Corning, Corning, NY, USA) at a density of $1.25 \times 10^{5}$ cells/well and cultivated in $1 \mathrm{ml}$ of DMEM-FCS for $24 \mathrm{~h}$. Immediately after the medium was exchanged by fresh OptiMEM medium (Invitrogen), the PIC solution $(50 \mu \mathrm{l})$ was added and incubated for $15 \mathrm{~min}$ at room temperature, followed by $6 \mathrm{~h}$ incubation for cell gene transfection. Then, the medium was changed to DMEM-FCS and cells were incubated for another $24 \mathrm{~h}$.

Cells were washed with PBS twice, lysed in $100 \mu$ of cell culture lysis reagent (Promega, Madison, WI, USA), transferred into a micro reaction tube, and the cell debris was separated by centrifugation $\left(14 \times 10^{3} \mathrm{rpm}, 20 \mathrm{~min}\right)$. Then, $100 \mu \mathrm{lu}$ ciferase assay reagent (Promega) was added to $20 \mu \mathrm{l}$ of supernatant, while the relative light unit (RLU) of the samples was determined by a luminometer (MicroLumatPlus LB 96V, Berthold, Tokyo, Japan). The total protein of each well was determined with the bicinchonic acid (BCA) protein assay kit (Pierce, Rockford, IL, USA) according to the manufacturers' instructions in order to normalize the 
influence of number variance of cells on the luciferase activity. Each experimental group was carried out three times independently.

\subsection{Evaluation of Plasmid DNA Internalization}

Plasmid DNA was labeled with rhodamine using a Label IT $^{\circledR}$ CX-Rhodamine Labeling Kit (Mirus ${ }^{\circledR}$, Madison, WI, USA) according to the manufacturers' instructions. After transfection culture wuth the rhodamine-labeled plasmid DNA, the cells were treated in cold acetate-buffered solution containing 0.3 vol\% acetic acid, $85.0 \mathrm{mM} \mathrm{NaCl}$ and $5.0 \mathrm{mM} \mathrm{KCl}$ for $1 \mathrm{~min}$, then the cells were washed with cold PBS to remove the complexes bound onto the cell surface. The cells of three wells were collected by the trypsinization, and the results were considered as an average value of triplicates, while $1 \times 10^{4}$ cells were measured by the fluorescence activated cell sorter (FACSCalibur, Becton Dickinson, Franklin Lakes, NJ, USA) with Cell Quest Pro Software. The percentage of rhodamine-positive cells was calculated by setting the background population as $98 \%$ negative when analyzing control cells [21].

\subsection{Cell Viability}

Cytotoxicity was assayed using a cell counting kit (Nacalai Tesque). Cells were seeded in each well of a 96 multi-well cluster plate (Corning) at a density of $1.25 \times 10^{4}$ cells/well and cultivated in DMEM-FCS for $24 \mathrm{~h}$. The medium was changed to fresh OptiMEM medium, and $5 \mu \mathrm{l}$ of the PIC solution was applied to each well, followed by $6 \mathrm{~h}$ incubation. Then, the medium was changed to DMEMFCS, $10 \mu \mathrm{l}$ 2-(2-methoxy-4-nitrophenyl)-3-(4-nitrophenyl)-5-(2,4-disulfophenyl)2H-tetrazolium (WST-8) solution was added and the cells were incubated for $3 \mathrm{~h}$. The absorbance of samples was measured at $450 \mathrm{~nm}$ in a VERSAmax microplate reader (Molecular Devices). The percent cell viability was expressed as $100 \%$ for control (non-treated cells).

\subsection{Statistical Analysis}

All the data were expressed as the mean \pm the standard deviation of the mean. Statistical analysis was performed based on the ANOVA, followed by Fisher's PLSD and significance was accepted at $P<0.05$.

\section{Results}

\subsection{Characterization of Cationized Dextrans}

To characterize cationized dextrans in terms of buffering capacity, the acid-base titration of the cationized dextrans was performed (Fig. 2). The curve profiles depended on the type of amine compounds introduced to dextran. The $\mathrm{p} K_{\mathrm{a}}$ values of cationized dextran were determined by the curves (Table 1 ). The $\mathrm{p} K_{\mathrm{a}}$ values of cationized dextran decreased compared with those of original amine compounds 


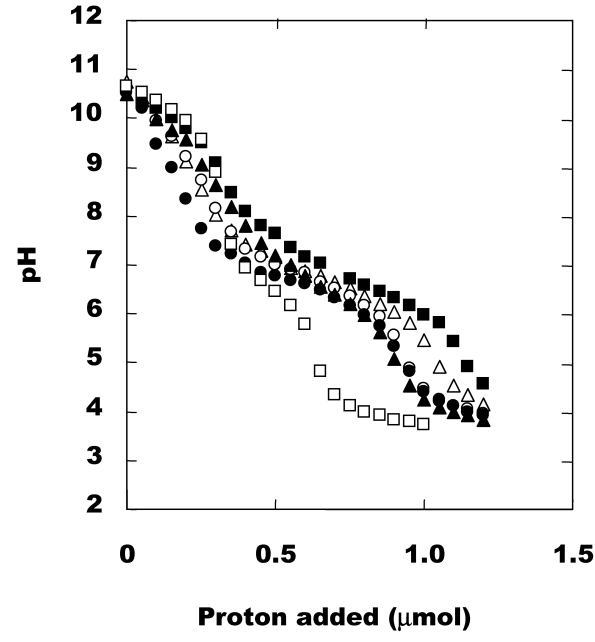

(A)

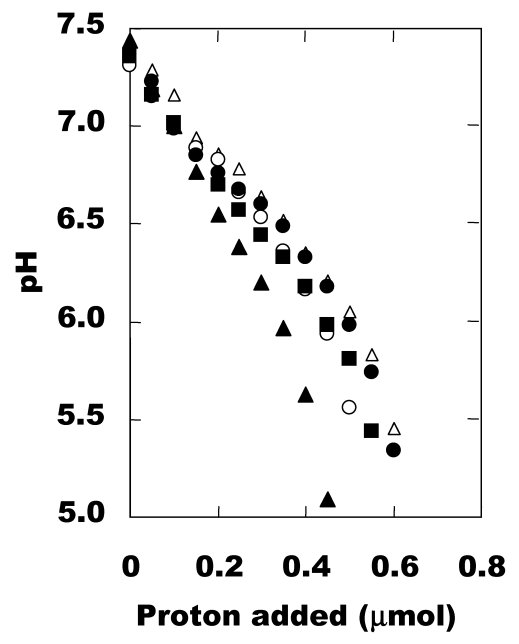

(B)

Figure 2. (A) Acid-base titration curves of cationized dextran or water ( $\square$ ). The amine compound used for cationization is $(\bullet) \mathrm{N} 2 \mathrm{~N},(\boldsymbol{\Delta}) \mathrm{N} 2 \mathrm{~N} 2,(\boldsymbol{\square}) \mathrm{N} 2 \mathrm{~N} 2,2,(\mathrm{O}) \mathrm{N} 3 \mathrm{~N} 4 \mathrm{~N}$ and $(\triangle)$ N3N4N3N. (B) Replotted $\mathrm{pH}$ change profiles of cationized dextran as a function of the proton addition.

used for cationization. Figure 2B shows the replotted $\mathrm{pH}$ change profiles of cationized dextran as a function of proton addition. When the proton amounts required for $\mathrm{pH}$ change from 7.4 to 5.0 were calculated, the order was $\mathrm{N} 3 \mathrm{~N} 4 \mathrm{~N} 3 \mathrm{~N}>\mathrm{N} 2 \mathrm{~N}>$ $\mathrm{N} 2 \mathrm{~N} 2,2>\mathrm{N} 3 \mathrm{~N} 4 \mathrm{~N}>\mathrm{N} 2 \mathrm{~N} 2$.

\subsection{Characterization of Cationized Dextran-Plasmid DNA Complexes}

To confirm the formation of polyion complexes and characterize their physicochemical properties, electrophoresis analysis, DLS and ELS measurement, EtBr intercalation assay were performed. Figure 3 shows the agarose gel electrophoresis images of cationized dextran-plasmid DNA complexes prepared at different N/P ratios. For all the complexes, the migration of plasmid DNA was retarded with an increase in the N/P ratio, and the plasmid DNA disappeared at the N/P ratio higher than a certain value. The extents of retardation in each N/P ratio were different among cationized dextrans used for complexation.

The physicochemical properties of polyion complexes prepared at the N/P ratio of 5.0 are summarized in Table 1. The apparent molecular size and the zeta potential of free plasmid DNA were around $660 \mathrm{~nm}$ and $-15 \mathrm{mV}$, respectively. The apparent molecular size of plasmid DNA complexed with amine derivatives of dextran, except for N2N2-introduced dextran, became smaller than that of free plasmid DNA. On the other hand, the zeta potential was positive for all the plasmid DNA complexes with cationized dextran, while the values depended on the type of cationized dextrans used for complexation.

Figure 4 shows the solution fluorescence of cationized dextran-plasmid DNA complexes prepared at different N/P ratios after EtBr addition. The EtBr fluores- 


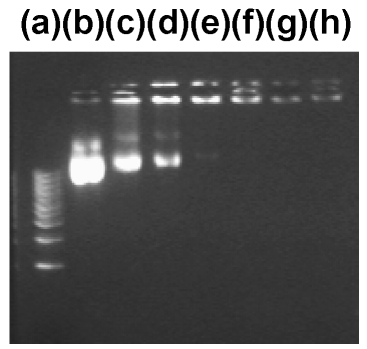

(A)

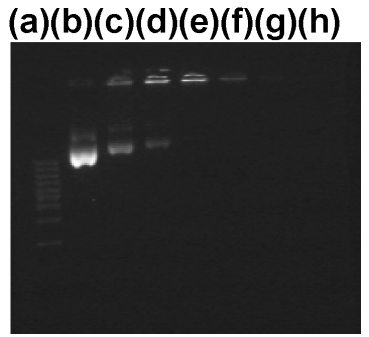

(D)

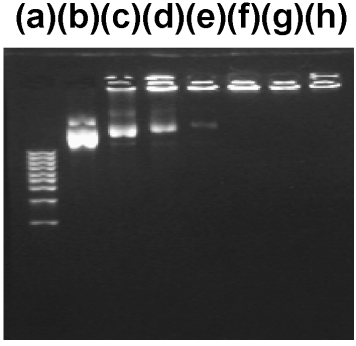

(B)

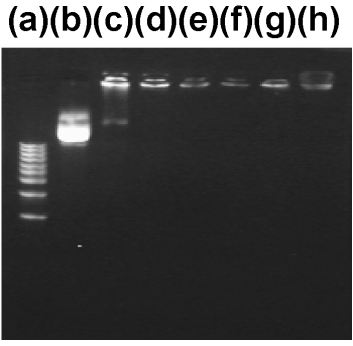

(C)

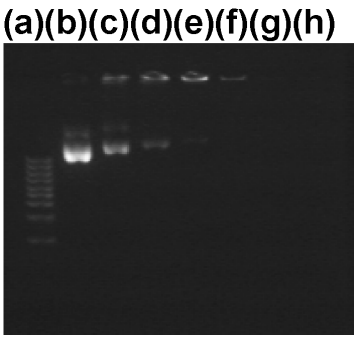

(E)

Figure 3. Agarose gel electrophoresis of cationized dextran-plasmid DNA complexes prepared at different N/P ratios. The amine compound used for cationization is (A) N2N, (B) N2N2, (C) N2N2,2, (D) N3N4N and (E) N3N4N3N. The sample applied is (a) DNA marker, (b) free plasmid DNA and (c-h) complexes prepared at N/P ratios of (c) 0.5, (d) 1.0, (e) 1.5, (f) 2.0, (g) 3.0 and (h) 5.0.

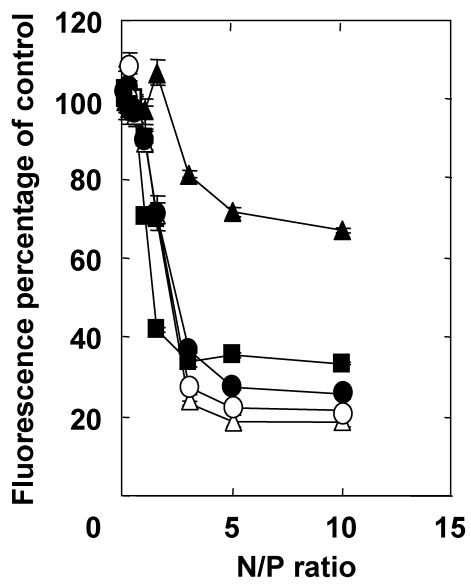

Figure 4. Solution fluorescence of cationized dextran-plasmid DNA complexes prepared at different $\mathrm{N} / \mathrm{P}$ ratios after EtBr addition. The amine compound used for cationization is $(\bullet) \mathrm{N} 2 \mathrm{~N},(\boldsymbol{\Delta}) \mathrm{N} 2 \mathrm{~N} 2$, (ם) $\mathrm{N} 2 \mathrm{~N} 2,2,(\bigcirc) \mathrm{N} 3 \mathrm{~N} 4 \mathrm{~N}$ and $(\triangle) \mathrm{N} 3 \mathrm{~N} 4 \mathrm{~N} 3 \mathrm{~N}$.

cence intensity decreased with an increase in the N/P ratio. The pattern of fluorescence intensity decreased depended on the amine compounds introduced to dextran. At the N/P ratio of 5.0, the EtBr fluorescence intensity became low for the PIC prepared by the cationized dextrans, except for N2N2-introduced dextran. 


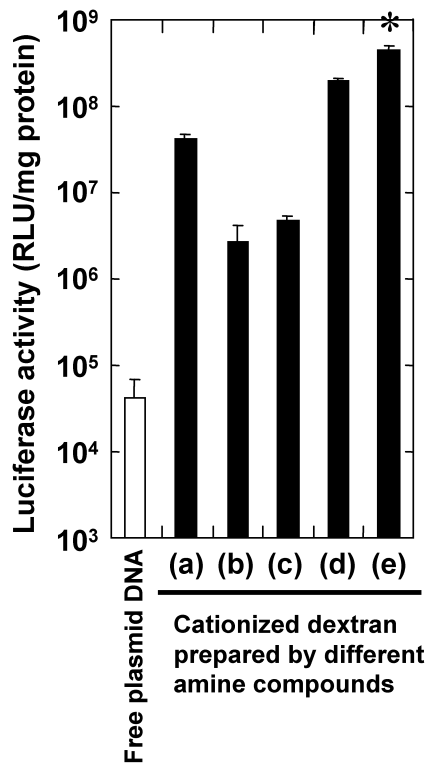

Figure 5. Effect of the amine compound introduced on the luciferase expression of cationized dextran-plasmid DNA complexes for HeLa cells. The amine compound used for cationization is (a) N2N, (b) N2N2, (c) N2N2,2, (d) N3N4N or (e) N3N4N3N. The amount of plasmid DNA applied is $2.5 \mu \mathrm{g} / \mathrm{well}$ and the $\mathrm{N} / \mathrm{P}$ ratio is $5.0 .{ }^{*} P<0.05$ versus the expression level by complexes prepared with other cationized dextrans.

\subsection{In Vitro Gene Transfection of Cationized Dextran-Plasmid DNA Complexes}

The in vitro gene transfection for HeLa cells was performed by the plasmid DNA complexed with various cationized dextrans to evaluate the effect of amine type on the level of gene expression, the cellular internalization efficiency. Figure 5 shows effect of the amine compound introduced on the luciferase expression of cationized dextran-plasmid DNA complexes for HeLa cells. The level of gene expression was different among the cationized dextrans used. The highest level was observed for the complex of cationized dextran with N3N4N3N-introduced dextran.

Table 1 summarizes the internalization percentages of complexes with cationized dextrans into Hela cells. The highest internalization percentage was observed for the complex of spermine-introduced dextran and plasmid DNA.

Figure 6 shows the effect of the amine compound introduced on the cell viability of HeLa cells transfected with cationized dextran-plasmid DNA complexes prepared at the N/P ratio of 5.0. No cytotoxicity was observed for every complex under the condition where the cell transfection experiment is performed.

\section{Discussion}

The present study demonstrates that the in vitro gene expression of plasmid DNA was greatly enhanced by the complexation with the cationized dextran compared 


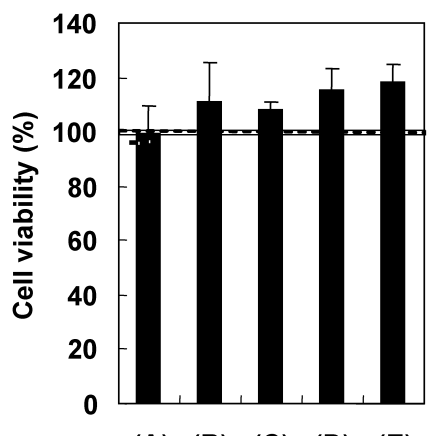

(A) (B) (C) (D) (E)

Figure 6. Effect of the amine compound introduced on the cell viability of HeLa cells transfected with cationized dextran-plasmid DNA complexes prepared at a N/P ratio of 5.0. The amine compound used for cationization is (A) N2N, (B) N2N2, (C) N2N2,2, (D) N3N4N and (E) N3N4N3N.

with that by free plasmid DNA and influenced by the type of amine compounds introduced to dextran. In general, for efficient non-viral gene delivery it is important to design carriers that can electrostatically bind to a genetic material, molecularly condense the material size to a diameter range of several hundred nanometers, protect the material from enzymatic degradation, enhance the cell internalization and possess a buffering effect to escape from the endosome. In this study, the physicochemical properties of complexes were modified by chemical introduction of different amine compounds used. This derivatization resulted in the different levels of gene expression.

Dextran is a water-soluble, naturally-occurring polysaccharide with multiple hydroxyl groups applicable to chemical modification. It also has low immunogenicity and a long history in clinical use as a plasma expander [22]. Gene delivery systems have been investigated by making use of cationized polysaccharides, such as cationized dextran [23-25], schizophyllan [26] and chitosan [27]. Previously, it has been demonstrated that the polysaccharide molecular weight [28] and the extent of amine compounds [29] introduced to the polysaccharide greatly affect the physicochemical properties of complexes with plasmid DNA and the level of gene expression. Therefore, in this study, the effect of amine compounds introduced to dextran on the physicochemical property of complex and the level of gene expression were investigated.

In this study, five different amine compounds were selected (Fig. 1). Ethylenediamine $(\mathrm{N} 2 \mathrm{~N})$, spermidine $(\mathrm{N} 3 \mathrm{~N} 4 \mathrm{~N})$ and spermine $(\mathrm{N} 3 \mathrm{~N} 4 \mathrm{~N} 3 \mathrm{~N})$ were selected because these polyamines are present in the body, while N-ethylethylenediamine $(\mathrm{N} 2 \mathrm{~N} 2)$ and $\mathrm{N}, \mathrm{N}$-diethylethylenediamine $(\mathrm{N} 2 \mathrm{~N} 2,2)$ were selected to compare the effect of amine structure on the physicochemical property and the gene expression level of cationized dextran complexes. Acid-base titration (Fig. 2A) revealed that the $\mathrm{p} K_{\mathrm{a}}$ values of cationized dextran decreased compared with those of original amine compounds used for cationization. This is due to the compound basicity. It is possible that the chemical introduction of amine compounds with the hydroxyl 
group of dextran produces the amide bond of a electron-withdrawn group, which makes the terminal amino group positive via the so-called inductive effect.

DLS and ELS measurements (Table 1) and the EtBr intercalation assay (Fig. 4) revealed that the amine compound introduced to dextran greatly affected on the physicochemical properties of plasmid DNA complexes. As shown in Table 1, after complexation with dextran cationized by amine compounds, except N2N2, the apparent molecular size of plasmid DNA became smaller, while the apparent size of complexes using N2N2-introduced dextran was larger in comparison with that of the free plasmid DNA. The EtBr intercalation assay (Fig. 4) revealed that the strength of interaction between the plasmid DNA and N2N2-introduced dextran was lower than that of other cationized dextrans. These findings may be due to the steric hindrance of ethylene groups next to the secondary amine. This structure would result in the formation of a loosely bound complex. Based on these results, the interaction strength between the plasmid DNA and N2N2-introduced dextran was too weak to allow the plasmid DNA to condense sufficiently. As the result, the large-sized aggregation was formed. The zeta potential (Table 1) was positive for all complexes although the values depended on the type of cationized dextrans used for complexation. From the $\mathrm{p} K_{\mathrm{a}}$ determined, the percentage of amino groups protonized at $\mathrm{pH} 7.4$ can be calculated, which is $49,94,98,68$ and $72 \%$ for $\mathrm{N} 2 \mathrm{~N}$, $\mathrm{N} 2 \mathrm{~N} 2, \mathrm{~N} 2 \mathrm{~N} 2,2, \mathrm{~N} 3 \mathrm{~N} 4 \mathrm{~N}$ and N3N4N3N, respectively. The order of zeta potential is in good accordance with that of protonized percentage.

The level of gene expression depended on the amine groups introduced to dextran, while the order was N3N4N3N $>\mathrm{N} 3 \mathrm{~N} 4 \mathrm{~N}>\mathrm{N} 2 \mathrm{~N}>\mathrm{N} 2 \mathrm{~N} 2,2>\mathrm{N} 2 \mathrm{~N} 2$ (Fig. 5). This can be explained in terms of plasmid DNA internalized into the cells, the ability for the complexes to escape from the endosome and the ability for complex to be dissociated and translated in the nucleus. First, the order of plasmid DNA internalization was N3N4N3N $>\mathrm{N} 3 \mathrm{~N} 4 \mathrm{~N}>\mathrm{N} 2 \mathrm{~N} 2,2>\mathrm{N} 2 \mathrm{~N}>\mathrm{N} 2 \mathrm{~N} 2$ (Table 1). It has been reported that a certain range of apparent molecular size and surface state of PICs was effective for the enhancement of plasmid DNA internalization [30, 31]. The low percentage of plasmid DNA internalization for N2N2-introduced dextran is due to the large molecular size of the complex. Second, it is practically important to consider the buffering capacity in the $\mathrm{pH}$ range 7.4-5.0 for successful gene expression. When $\mathrm{pH}$ change profiles of cationized dextran from 7.4 to 5.0 were replotted as a function of proton addition, the order of proton amounts required for pH change was N3N4N3N $>$ N2N $>$ N2N2,2 $>$ N3N4N $>$ N2N2 (Fig. 2B). Third, the ability of complex for dissociation and translation is also important. Although there are no direct data in the present study, we have previously reported that the ability was nearly parallel to the result of the EtBr assay [29] (Fig. 4). When the order from Figs 2B and 4 and Table 1 is compared with that from Fig. 5, we can say with fair certainty that each step, such as plasmid DNA internalization, escape from the endosome and dissociation and translation of complex, governs the gene expression. However, more detailed studies about the intracellular fate and stability are required to understand the contribution to each step. 


\section{References}

1. W. F. Anderson, Science 256, 808 (1992).

2. M. J. During, Adv. Drug Deliv. Rev. 27, 83 (1997).

3. R. G. Vile, A. Tuszynski and S. Castleden, Mol. Biotechnol. 5, 139 (1996).

4. S. C. De Smedt, J. Demeester and W. E. Hennink, Pharm. Res. 17, 113 (2000).

5. K. Ewert, N. L. Slack, A. Ahmad, H. M. Evans, A. J. Lin, C. E. Samuel and C. R. Safinya, Curr. Med. Chem. 11, 133 (2004).

6. M. C. Pedroso de Lima, S. Neves, A. Filipe, N. Duzgunes and S. Simoes, Curr. Med. Chem. 10, $1221(2003)$.

7. A. Hirko, F. Tang and J. A. Hughes, Curr. Med. Chem. 10, 1185 (2003).

8. S. Zhang, Y. Xu, B. Wang, W. Qiao, D. Liu and Z. Li, J. Control. Rel. 100, 165 (2004).

9. M. E. Davis, Curr. Opin. Biotechnol. 13, 128 (2002).

10. M. D. Brown, A. G. Schatzlein and I. F. Uchegbu, Int. J. Pharm. 229, 1 (2001).

11. F. Noorman, M. M. Barrett-Bergshoeff, M. Bekkers, J. J. Emeis and D. C. Rijken, Thromb. Haemost. 78, 1249 (1997).

12. H. Hosseinkhani, T. Azzam, Y. Tabata and A. J. Domb, Gene Ther. 11, 194 (2004).

13. J. Jo and Y. Tabata, Eur. J. Pharm. Biopharm. 68, 90 (2008).

14. D. Fischer, A. von Harpe, K. Kunath, H. Petersen, Y. Li and T. Kissel, Bioconjug. Chem. 13, 1124 (2002).

15. A. Akinc, D. M. Lynn, D. G. Anderson and R. Langer, J. Am. Chem. Soc. 125, 5316 (2003).

16. S. J. Tseng, S. C. Tang, M. D. Shau, Y. F. Zeng, J. Y. Cherng and M. F. Shih, Bioconjug. Chem. 16, 1375 (2005).

17. Y. Liu and T. M. Reineke, Bioconjug. Chem. 18, 19 (2007).

18. A. V. Slita, N. A. Kasyanenko, O. V. Nazarova, I. I. Gavrilova, E. M. Eropkina, A. K. Sirotkin, T. D. Smirnova, O. I. Kiselev and E. F. Panarin, J. Biotechnol. 127, 679 (2007).

19. C. Lin and J. F. J. Engbersen, J. Control. Rel. 132, 267 (2008).

20. G. T. Hermanson, Bioconjugate Techniques. Academic Press, San Diego, CA (1996).

21. F. Lampariello, Cytometry 15, 294 (1994).

22. U. Klotz and H. Kroemer, Clin. Pharmacokinet. 12, 123 (1987).

23. T. Azzam, H. Eliyahu, L. Shapira, M. Linial, Y. Barenholz and A. J. Domb, J. Med. Chem. 45, 1817 (2002).

24. T. Azzam, A. Raskin, A. Makovitzki, H. Brem, P. Vierling, M. Lineal and A. J. Domb, Macromolecules 35, 9947 (2002).

25. A. Vaheri and J. S. Pagano, Virology 27, 434 (1965).

26. T. Nagasaki, M. Hojo, A. Uno, T. Satoh, K. Koumoto, M. Mizu, K. Sakurai and S. Shinkai, Bioconjug. Chem. 15, 249 (2004).

27. T. Ishii, Y. Okahata and T. Sato, Biochim. Biophys. Acta 1514, 51 (2001).

28. J. Jo, T. Ikai, A. Okazaki, K. Nagane, M. Yamamoto, Y. Hirano and Y. Tabata, J. Biomater. Sci. Polymer Edn 18, 883 (2007).

29. J. Jo, T. Ikai, A. Okazaki, M. Yamamoto, Y. Hirano and Y. Tabata, J. Control. Rel. 118, 389 (2007).

30. M. Nishikawa and L. Huang, Human Gene Ther. 12, 861 (2001).

31. X. Zhou and L. Huang, Biochim. Biophys. Acta 1189, 195 (1994). 
Copyright of Journal of Biomaterials Science -- Polymer Edition is the property of VSP International Science Publishers and its content may not be copied or emailed to multiple sites or posted to a listserv without the copyright holder's express written permission. However, users may print, download, or email articles for individual use. 